\title{
Four New Species of Oswaldocruzia (Nematoda: Trichostrongylina, Molineoidea) Parasitizing Amphibians and Lizards from Ecuador
}

\author{
Badreddine Ben Slimane, Marie-Claude Durette-Desset ${ }^{+}$
}

\begin{abstract}
Laboratoire de Protozoologie et Parasitologie coniparée de l'E.P.H.E. \& Laboratoire de Biologie Parasitaire, Protistologie, Helminthologie, associé au C.N.R.S., Muséum National d'Histoire Naturelle, 61 Rue Buffon,
\end{abstract} 75231 Paris Cedex 05, France

Description of four new species of Oswaldocruzia parasitizing Iguanidae and Leptodactylidae from Ecuador, demonstrate that they are morphologically close to each other. Like most of the other neotropical and holarctic Oswaldocruzia, they are characterized by spicules with three main branches: blade, shoe and fork; the division of the fork within the distal third of the spicule length appears to be characteristic of the neotropical species.

- Oswaldocruzia bainae n. sp. parasitizing Anolis chrysolepis and Anolis fuscoauratus possesses a synlophe visible only on transversal sections of the body. It is composed of rounded and not pointed ridges.

- Oswaldocruzia tcheprakovae $n$. sp. parasitizing Eleutherodactylus altamazonicus is closely related to $\mathrm{O}$. bainae, but the synlophe is present only in the anterior and posterior extremities of the body.

- Oswaldocruzia cassonei $n$. sp. parasitizing Eleutherodactylus lanthanites is closely related to $\mathrm{O}$. taranchoni, Ben Slimane and Durette-Desset, 1995, a parasite of Bufo marinus from Brazil. It is differentiated by the synlophe and the measurements.

- Oswaldocruzia petterae n. sp. parasitizing Leptodactylus pentadactylus is closely related to O. chambrieri, Ben Slimane and Durette-Desset, 1993, parasitizing Bufo and Eleutherodactylus in the same region. It is differentiated since, for an equivalent length of the body, the ridges are almost two times fewer and the spicules smaller.

Key words: Oswaldocruzia n. spp.- Nematoda - Trichostrongylina - lguanidae - Leptodactylidae - Ecuador

In this study, we continue the review of the genus Oswaldocruzia Travassos, 1917, a cosmopolitan parasite of Amphibians and Reptiles. The diagnosis of the species relies on new morphological criteria, particularly the synlophe characteristics in oesophageal region, the relative arrangement of rays 6 and 8 of the caudal bursa and the acute spicular morphology.

Six species of Oswaldocruzia were described in Ecuador (cf Ben Slimane \& Durette-Desset, 1993, 1995), but only from Amphibians. We describe below three new species in Amphibians and one in Reptiles.

\section{MATERIALS AND METHODS}

The Nematodes were collected in the small intestine of Ecuadorian Leptodactylidae and Iguanidae (neotropical fauna, guyano-brazilian sub-zona).

\footnotetext{
${ }^{+}$Corresponding author. Fax: 33-1-40 7934 99. E-mail: mcdd@ cimrs 1. mnhn.fr

Received 24 November 1995

Accepted 23 January 1996
}

The study of the synlophe is based on the Durette-Desset (1985) method; the nomenclature of the synlophe in oesophageal region follows Ben Slimane et al. (1993). More particularly, the cervical alae are defined as one or more latero-ventral ridges, more developed than the other ridges. The nomenclature of the caudal bursa follows Durette-Desset and Chabaud (1981), concerning the relative arrangement of rays 6 and 8 follows that of Durette-Desset et al. (1992). The spicules were studied after dissection and the nomenclature is that of Ben Slimane et al. (1993).

The material was stored in $70^{\circ}$ ethanol and deposited in the Helminthological Collections of the Muséum National d'Histoire Naturelle of Paris (MNHN) and in those of the Muséum d'Histoire Naturelle of Genève (MHNG).

\section{DESCRIPTION}

The species are closely related to each other and to the other species previously studied in the same region. Some characters do not provide specific differences and can be defined similarly for all the species. 
Head: cephalic vesicle present without anterior swelling. En face view: buccal aperture triangular, with 6 externo-labial papillae, 4 cephalic papillae and 2 amphids. Small dorsal oesophageal tooth present.

Anterior extremity: excretory pore situated within distal third of oesophagus. Triangular-shaped deirids, posterior to excretory pore. Well developed excretory glands. Musculo-glandular separation of oesophagus acutely visible at nerve ring level.

Caudal bursa: with 2-3 pattern which tends towards 2-1-2 i.e extremities of rays 4 directed towards anterior of body, nearer those of rays 3 than rays 5 . Rays 2 and 3 joined along, rays 5 and 6 joined along. Rays 8 arising on root of dorsal ray and overlapped by rays 6 except in their distal extremity (type III). Rays 9 arising on dorsal ray before division of the latter into two branches of which internal ones are longest. Thick dorsal ray. Gubernaculum absent.

Genital cone: $15 \mu \mathrm{m}$ high by $15 \mu \mathrm{m}$ wide at its proximal part, bearing on anterior lip a large papilla "zero" and 2 min papillae 7 on posterior lip. Spicules: divided proximally into three main branches: extemo-lateral branch or blade, internodorsal branch or shoe, interno-ventrat branch or fork. Fork divided within distal third of spicule. Female: didelphic with very short infundibula.

\section{Oswaldocruzia bainae n. sp.}

Type-material: holotype male, allotype female MHNG-INVE 19484; 1 male, 3 females paratypes MNHN 212 MD

Host: Anolis chrysolepis (Iguanidae)

Site: small intestine

Locality: San Pablo, Ecuador

Voucher specimens: from the same site and the same locality as the types

In 9 Anolis chrysolepis: 11 males, 5 L4 males, 16 females, 10 L4 females, MHNG-INVE 19485 to 19491. 7 male, 1 L4 male, 9 females, 1 entsheathed LA female, 2 L4 females MNHN 206 MD-207 MD. In 6 Anolis fuscoauratus: 12 males, 3 females: MHNG-INVE 19492-19497; 2 males , 4 females: MNHN 219 MD.

\section{ADULTS}

Small nematodes with anterior part of body coiled or not. Cervical alae absent.

Synlophe: (studied in 1 male and 1 female paratypes, 1 male and 1 female from A. chrysolepis 2 males from A. fuscoauratus. Numbers in brackets correspond to voucher specimens).

In both sexes, cuticle bears longitudinal "pseudoridges" or undulations, uninterrupted whole length of body but obvious only in trans- versal sections (Fig. 1C). In male 65\% (74 to $77 \%$ ) of ridges appear in oesophageal region, within $67 \%$ (74 to $78 \%$ ) of dorsal ridges and 63\% (71 to $81 \%$ ) of ventral ridges. In female $81 \%(71 \%)$ of ridges appear in oesophageal region within same dorsal and ventral ratio. Ridges disappear just anterior to caudal bursa in male and at phasmids level in female.

In male $27(30,34,26)$ ridges at oesophago-intestinal junction (Fig. 1C) and $40(40,44,35)$ at midbody (Fig. 1D). In female, 44 (34) ridges at oesophago-intestinal junction and 54 (48) at midbody (Fig. 1E).

In transversal sections, rounded ridges are more or less regularly spaced.

Holotype-male: $7100 \mu \mathrm{m}$ long and $130 \mu \mathrm{m}$ wide at mid-body. Cephalic vesicle $75 \mu \mathrm{m}$ long and 40 $\mu \mathrm{m}$ wide. Nerve ring, excretory pore and deirids $190 \mu \mathrm{m}, 380 \mu \mathrm{m}$ and $400 \mu \mathrm{m}$ from apex, respectively. Oesophagus $530 \mu \mathrm{m}$ long.

Caudal bursa illustrated in Fig. 1K. Spicules 190 $\mu \mathrm{m}$ long, blade divided at its distal part into two small branches which are subdivided into numerous processes; fork distally divided at $17 \%$ of whole length of spicule (Fig. 1H-J).

Allotype-female: $12350 \mu \mathrm{m}$ long and $190 \mu \mathrm{m}$ wide at mid-body. Cephalic vesicle $90 \mu \mathrm{m}$ long and 40 $\mu \mathrm{m}$ wide. Nerve ring, excretory pore and deirids $190 \mu \mathrm{m}, 370 \mu \mathrm{m}$ and $390 \mu \mathrm{m}$ from apex, respectively. Oesophagus $540 \mu \mathrm{m}$ long (Fig. 1A).

Vulva $4150 \mu \mathrm{m}$ from caudal extremity, vagina vera $50 \mu \mathrm{m}$ dividing vestibule $380 \mu \mathrm{m}$ long into two equivalent parts. Sphincters both $40 \mu \mathrm{m}$ long and infundibula both $30 \mu \mathrm{m}$ long (Fig.1F). Uterine branches both $2450 \mu \mathrm{m}$ long with 70 eggs. All eggs at morula stage, $70 \mu \mathrm{m}$ long and $50 \mu \mathrm{m}$ wide. Tail $160 \mu \mathrm{m}$ long and $70 \mu \mathrm{m}$ wide at level of anus, with caudal spine $16 \mu \mathrm{m}$ long (Fig. 1G).

ENTSHEATHED IMMATURE STAGES: (studied in 1 male and 1 female from A. chrysolepis). Male: $3200 \mu \mathrm{m}$ long and $90 \mu \mathrm{m}$ wide at mid-body. Nerve ring, excretory pore and deirids $170 \mu \mathrm{m}, 310$ $\mu \mathrm{m}$ and $330 \mu \mathrm{m}$ from apex, respectively. Oesophagus $390 \mu \mathrm{m}$ long; beginning of formation of bursate rays (Fig. 2E).

Female: $4100 \mu \mathrm{m}$ long and $90 \mu \mathrm{m}$ wide at midbody. Nerve ring, excretory pore and deirids 150 $\mu \mathrm{m}, 250 \mu \mathrm{m}$ and $250 \mu \mathrm{m}$ from apex, respectively. Oesophagus $370 \mu \mathrm{m}$ long; tail $150 \mu \mathrm{m}$ long and $40 \mu \mathrm{m}$ wide at level of anus with caudal spine 18 $\mu \mathrm{m}$ long.

Synlophe: same shape as in adult (Fig. 2D).

4TH STAGE LARVA: (studied in 1 male and 1 female from A. chrysolepis)

Head: cephalic vesicle absent (Fig. 2A).

Synlophe: in both sexes composed of two lateral 


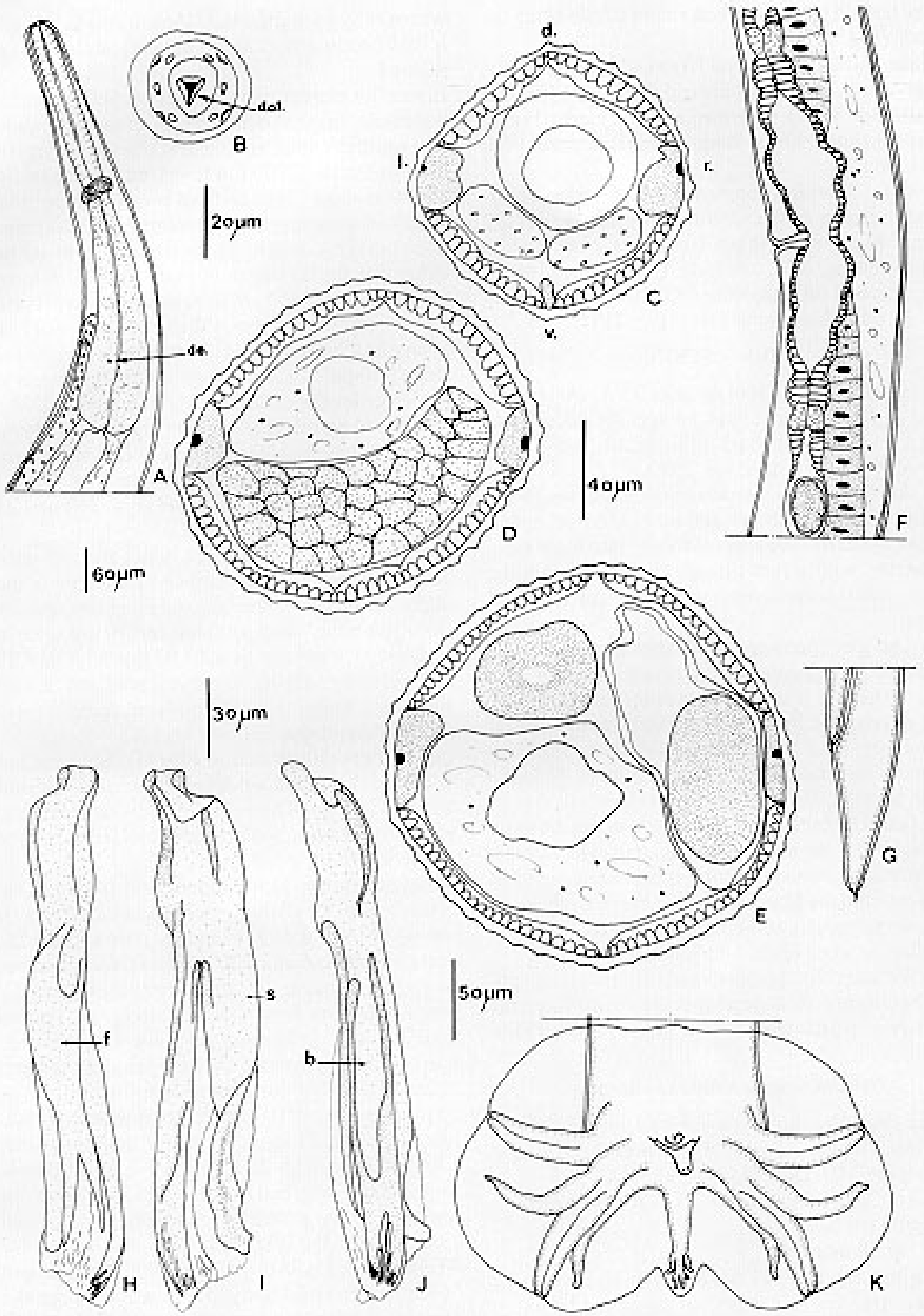

Fig. 1: Oswaldocruzia bainae n. sp. from Anolis chrysolepis: Adults - A: female, anterior extremity, left lateral view. B: male, head, apical view. C to E: synlophe in transversal sections. C: male, at oesophago-intestinal junction. D: male, at mid-body. E: female, $i d$. F: female, ovejector, left lateral view. G: female, tail, left lateral view. H to J: male, dissected left spicule. H: ventral view. I: dorsal view. J: externo-lateral view. K: male, caudal bursa, ventral view. All the sections are orientated as C. A, F, G bar $=60 \mu \mathrm{m} ; \mathrm{C}, \mathrm{D}, \mathrm{E}$ bar $=40 \mu \mathrm{m} ; \mathrm{B}$ bar $=20 \mu \mathrm{m} ; \mathrm{H}, \mathrm{I}, \mathrm{J}$ bar $=30 \mu \mathrm{m} ; \mathrm{K}$ bar $=50 \mu \mathrm{m}$. Abbreviations: d. = dorsal; v. = ventral; 1. = left; $\mathrm{r} .=$ right. de $=$ deirid; d.o.t $=$ dorsal oesophageal tooth; $\mathrm{f}=$ fork; $\mathrm{s}=$ shoe; $\mathrm{b}=$ blade. 
alae holded by chitinous skeleton whole along the body (Fig. 2C).

Male: $3400 \mu \mathrm{m}$ long and $80 \mu \mathrm{m}$ wide at mid-body. Nerve ring, excretory pore and deirids $175 \mu \mathrm{m}, 300$ $\mu \mathrm{m}$ and $320 \mu \mathrm{m}$ from apex, respectively. Oesophagus $390 \mu \mathrm{m}$ long. Genital apparat 1450 $\mu \mathrm{m}$ long.

Female: $3250 \mu \mathrm{m}$ long and $70 \mu \mathrm{m}$ wide at midbody. Nerve ring, excretory pore and deirids 150 $\mu \mathrm{m}, 240 \mu \mathrm{m}$ and $240 \mu \mathrm{m}$ from apex, respectively. Oesophagus $370 \mu \mathrm{m}$ long (Fig. 2A). Genital apparat $610 \mu \mathrm{m}$ long (Fig. 2G). Tail $110 \mu \mathrm{m}$ long by $30 \mu \mathrm{m}$ wide at anus level (Fig. $2 \mathrm{~F}$ ).

\section{DISCUSSION}

The specimens from Ecuadorian A. chrysolepis and $A$. fuscoauratus have no specific differentiation each other and belong to the genus Oswaldocruzia Travassos, 1917.

Among the numerous known species in the genus, those which present, as Ecuadorian specimens, spicules divided proximally into three main branches with a fork distally divided (within the distal third) seem characteristic of the neotropical zone.

The specimens described above possess: (1) a relative arrangement of the rays 6 and 8 of type III, i.e the rays 8 arise on root of the dorsal ray and are overlapped by the rays 6 except at their distal extremity; (2) a spicular blade distally divided into numerous processes; (3) a poor developed synlophe with undulations and not sharp ridges.

Only one other neotropical species has the same synlophe: O. peruensis Ben Slimane et al. (1995), a parasite of Peruvian Stenocercus roseiventris. It differs from the Ecuadorian specimens by the relative arrangement of the rays 6 and 8 (type II) and by the presence of the cervical alae.

We consider the specimens from Anolis spp. as belonging to a new species Oswaldocruzia bainae n.sp., named after our colleague, Dr Odile Bain.

\section{Oswaldocruzia tcheprakovae n.sp.}

Type-material: holotype male, allotype female MHNG-INVE 19506, 1 L4 male, 5 female paratypes MNHN, $178 \mathrm{MD}$

Host: Eleutherodactylus altamazonicus (Leptodactylidae)

Site: small intestine

Locality: San Pablo, Ecuador

\section{ADULTS}

Small nematodes, with anterior part of body coiled. Cervical alae absent.

Synlophe: (studied in the holotype and 1 paratype female). In both sexes, absence of synlophe except in anterior and posterior extremities of body where ridges longitudinal. According to sex and level of body, ridges are rounded (undulations) or pointed.

In anterior extremity, ridges appear behind cephalic vesicle. In male, dorsal ridges disappear at about $640 \mu \mathrm{m}$ from apex and ventral ones at about 700 $\mu \mathrm{m}$. In female (7000 $\mu \mathrm{m}$ long), dorsal ridges disappear at about $1200 \mu \mathrm{m}$ from apex (i.e three times length of oesophagus) and ventral ones at about $2400 \mu \mathrm{m}$ (i.e a third of whole length). In posterior extremity, dorsal ridges of male (3650 $\mu \mathrm{m}$ long) visible at about $1400 \mu \mathrm{m}$ from caudal bursa in transversal section of body but in toto, only at approximatively $450 \mu \mathrm{m}$; ventral ridges visible at about $250 \mu \mathrm{m}$. In female, ventral ridges appear at ovejector level and dorsal ones at anus level.

In male, 16 dorsal ridges at $1400 \mu \mathrm{m}$ to caudal bursa (Fig. 3I). In female, 26 ridges (13 dorsal, 13 ventral) at oesophago-intestinal junction (Fig. 3B), 13 ventral ridges at ovejector level (Fig. 3G) and 21 ridges at anus level (Fig. 3H).

In transversal section, pointed ridges are orientated perpendicularly to body surface. Undulations and ridges are both with same size and irregularly spaced. Holotype-male: $3650 \mu \mathrm{m}$ long and $70 \mu \mathrm{m}$ wide at mid-body. Cephalic vesicle $50 \mu \mathrm{m}$ long and 30 $\mu \mathrm{m}$ wide. Nerve ring, excretory pore and deirids $140 \mu \mathrm{m}, 230 \mu \mathrm{m}$ and $250 \mu \mathrm{m}$ from apex, respectively. Oesophagus $370 \mu \mathrm{m}$ long.

Caudal bursa illustrated in Fig. 4H. Spicules not dissected, $130 \mu \mathrm{m}$ long. Blade divided at its distal part into two small branches. Subdivision of small branches not seen. Fork distally divided at $28 \%$ of whole length of spicule.

Allotype-female: $7350 \mu \mathrm{m}$ long and $100 \mu \mathrm{m}$ wide at mid-body. Cephalic vesicle $50 \mu \mathrm{m}$ long and 30 $\mu \mathrm{m}$ wide. Nerve ring, excretory pore and deirids $150 \mu \mathrm{m}, 280 \mu \mathrm{m}$ and $300 \mu \mathrm{m}$ from apex, respectively. Oesophagus $400 \mu \mathrm{m}$ long (Fig. 4A).

Vulva $2600 \mu \mathrm{m}$ from caudal extremity. Vagina vera $30 \mu \mathrm{m}$ long dividing vestibule $180 \mu \mathrm{m}$ long into two parts, posterior one being slightly shorter. Sphincters both $30 \mu \mathrm{m}$ long and infundibula both $25 \mu \mathrm{m}$ long (Fig. 4D). Anterior uterine branch 1800 $\mu \mathrm{m}$ long with 31 eggs, posterior uterine branch $1700 \mu \mathrm{m}$ long with 28 eggs. All eggs at morula stage $70 \mu \mathrm{m}$ long and $40 \mu \mathrm{m}$ wide. Tail $140 \mu \mathrm{m}$ long and $50 \mu \mathrm{m}$ wide at level of anus, with caudal spine $15 \mu \mathrm{m}$ long (Fig. 4C).

4TH STAGE LARVA MALE: $2000 \mu \mathrm{m}$ long and $50 \mu \mathrm{m}$ wide at mid-body. Head without cephalic vesicle. Nerve ring, excretory pore and deirids 110 $\mu \mathrm{m}, 180 \mu \mathrm{m}$ and $190 \mu \mathrm{m}$ from apex, respectively. Oesophagus $360 \mu \mathrm{m}$ long. Synlophe composed of two lateral ridges orientated perpendicularly to body surface and supported by a chitinous skeleton (Fig. 4K). 

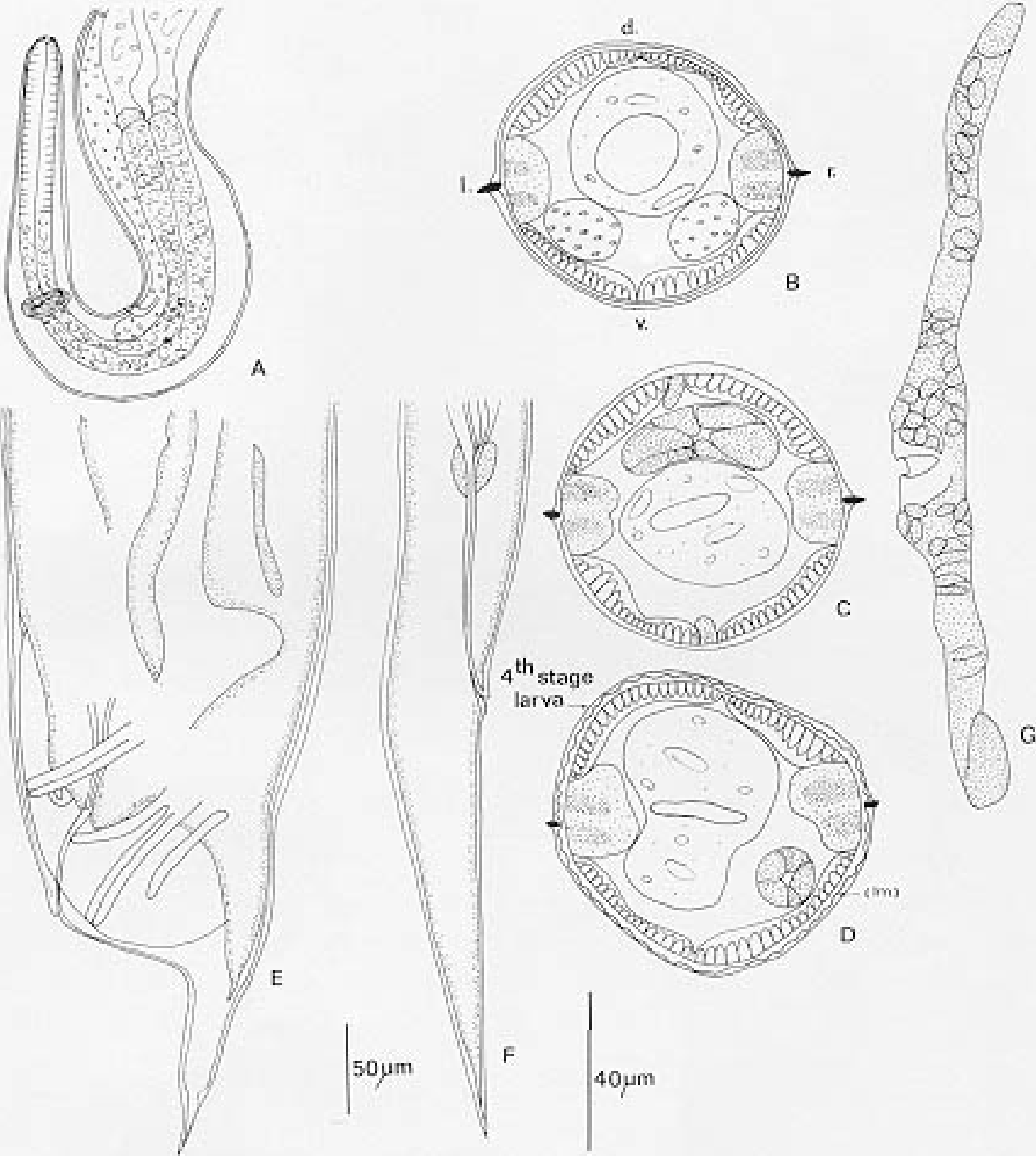

Fig. 2: Oswaldocruzia bainae n. sp from Anolis chrysolepis: 4th stage larvae and entsheathed immature stages (Im.) - A: L4 female, anterior extremity, right lateral view. B to D: synlophe in transversal sections. B: (Im.) female, at oesophago-intestinal junction, the immature synlophe is not yet formed. C: L4 male, at mid-body. D: (Im.) female, at mid-body, showing both L4 and (Im.) synlophes. E: (Im.) male, caudal bursa of the adult inside the tail of the L4, left lateral view. F: L4 female, tail, right lateral view. G: L4 female, genital apparat showing the beginning of the differentiation between the ovejector, the uterine branches and the ovaries, left lateral view. All sections are orientated as B. A, F bar $=50 \mu \mathrm{m}$; B to $\mathrm{G}$ bar $=40 \mu \mathrm{m}$. Abbreviations: $\mathrm{d} .=$ dorsal; v. = ventral; $1 .=$ left; r.= right; (Im.) = entsheathed immature in L4.

\section{DISCUSSION}

With a synlophe mainly composed of rounded and not pointed ridges, the species can be related to O. peruensis Ben Slimane et al. (1995) parasite of Sternocercus roseiventris in Peru and O. bainae n.sp. parasite of Anolis spp. It is closely related to the latter since the specimens described above, have an arrangement of rays 6 and 8 of type III and no cervical alae as $O$. bainae.

But the specimens of Eleutherodactylus altamazonicus can be distinguished from all the neotropical species by its very particular synlophe lacking ridges in the median part of the body.

We therefore consider the specimens from Eleutherodactilus altamazonicus as belonging to 

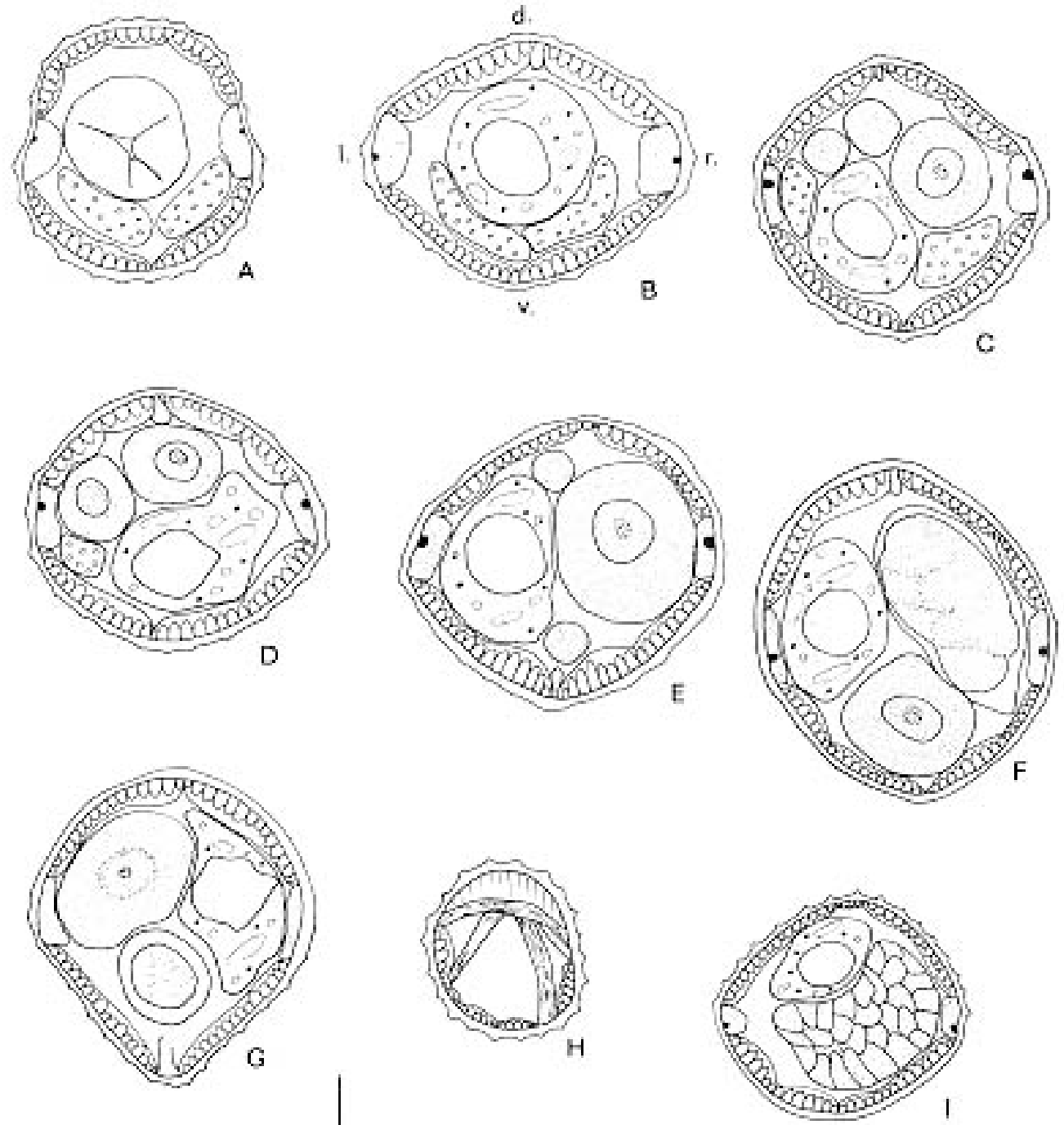

$40 \mu m$
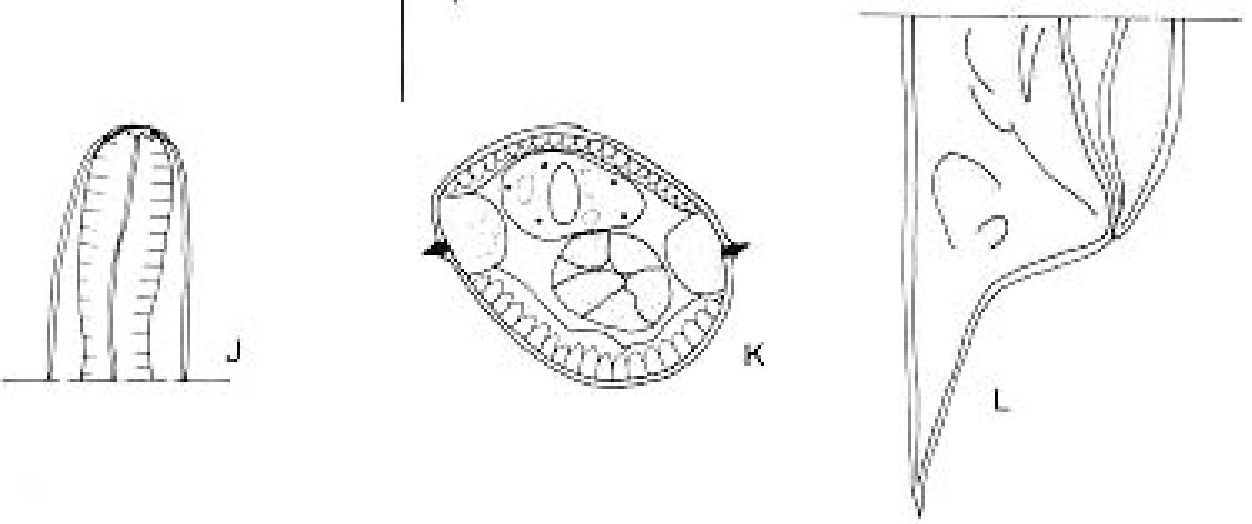

Fig.3: Oswaldocruzia tcheprakovae n.sp. from Eleutherodactylus altamazonicus. A-I: synlophe in transversal sections. A-H: female (7000 mm long). A: at excretory pore level. B: at oesophago-intestinal junction. C: at $830 \mu \mathrm{m}$ from apex (twice the length of oesophagus). D: at $1180 \mu \mathrm{m}$ from apex. E: at $2360 \mu \mathrm{m}$ from apex, at about level of the first third of body). F: at midbody. G: at ovejector level. H: at anus level. I: male, at $1400 \mu \mathrm{m}$ from the caudal bursa. J-L: L4 male. J: head, right lateral view. $\mathrm{K}$ : synlophe at mid-body. L: tail, right lateral view. All the sections are orientated as B. Abbreviations: d. = dorsal; v. = ventral; $1 .=$ left; $r=$ right. 


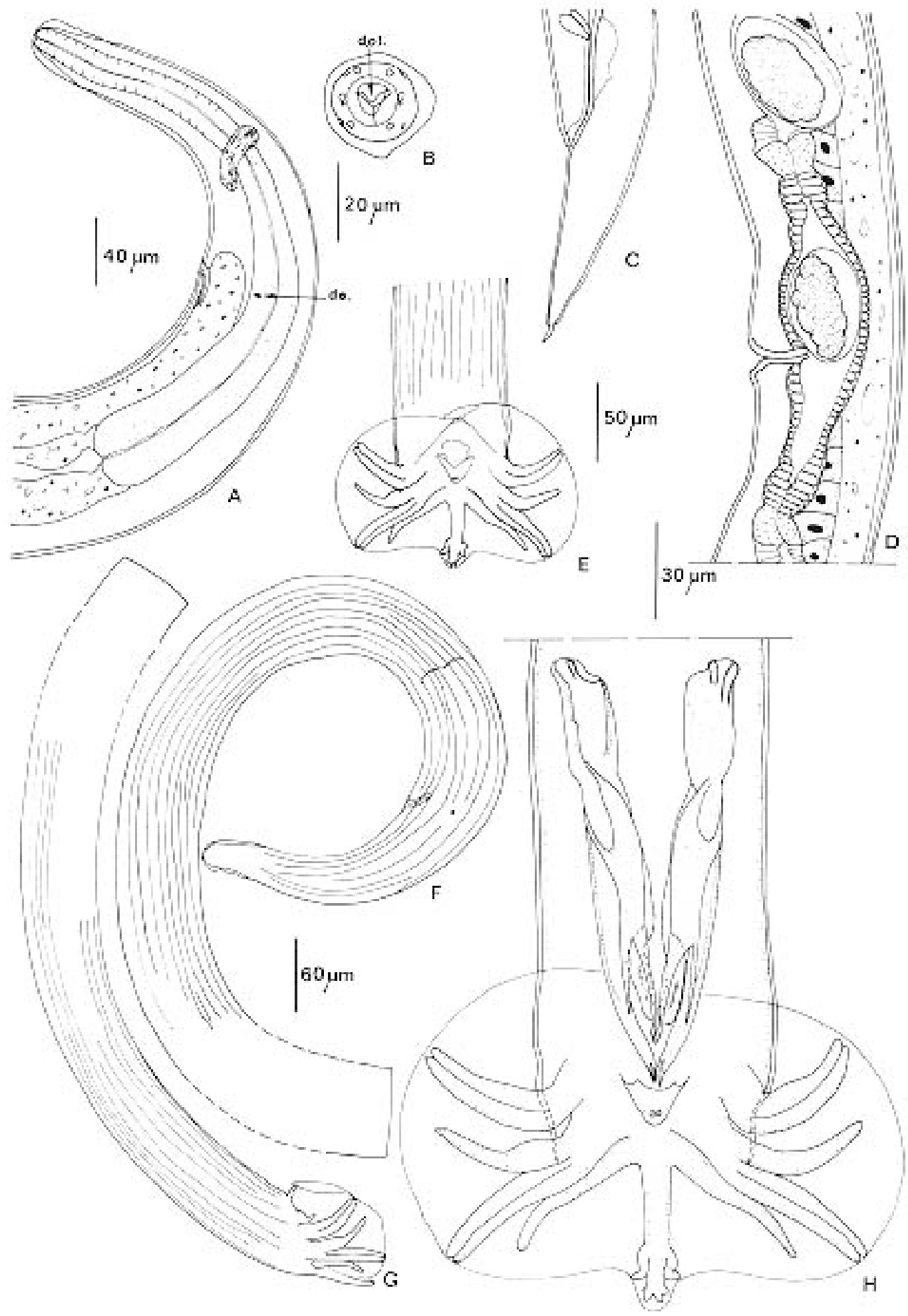

Fig. 4: Oswaldocruzia tcheprakovae n.sp. from Eleutherodactylus altamazonicus. A-D: female - A: anterior extremity, left lateral view. B: head, apical view. C: tail, left lateral view. D: ovejector, left lateral view. E-H: male. E: caudal bursa, showing the disappearance of the ventral ridges. F: anterior extremity, showing the appearance and the disappearance of the ridges, right lateral view. G: posterior extremity, showing the appearance and the disappearance of the ridges, right lateral view. $\mathrm{H}$ : caudal bursa, ventral view. A, C, D bar $=40 \mu \mathrm{m}$; B bar $=20 \mu \mathrm{m}$; E bar $=50 \mu \mathrm{m} ; \mathrm{F}, \mathrm{G}$ bar $=60 \mu \mathrm{m} ; \mathrm{H}$ bar $=30 \mu \mathrm{m}$. Abbreviations: de.= deirid; d.o.t $=$ dorsal oesophagal tooth. 
a new species Oswaldocruzia tcheprakovae n.sp. named after our colleague Roselyne Tcheprakoff.

\section{Oswaldocruzia cassonei n.sp.}

Type-material: holotype male, allotype female MHNG-INVE 19477, 4 males, 1 female MNHN, $169 \mathrm{MD}$

Host:Eleutherodactylus lanthanites (Leptodactylidae)

Site: small intestine

Locality: San Pablo, Ecuador

Voucher specimens: from the same site and the same locality, as the types

In 5 E. lanthanites: 3 males, 3 females MHNGINVE 19478-79, 3 males MNHN 170 MD- 172 MD. In 2 E. conspicillalus: 4 males MHNG- INVE 19480-81, 3 males MNHN 174 MD. In $1 E$. diadematus: 1 female MHNG-INVE 19482. In 1 E. altamazonicus: 1 male MHNG-INVE 19483.

\section{ADULTS}

Small nematodes, curved on ventral line. Cervical alae absent.

Synlophe: (studied in 2 male and 1 female paratypes, 2 males, parasites of E. lanthanites and 1 male, parasite of E. conspicillatus. Numbers in brackets correspond to voucher specimens).

In both sexes, cuticle bears uninterrupted longitudinal ridges. In male, $85-93 \%$ of ridges appear in oesophageal region within $79-100 \%$ of dorsal ridges and $87-100 \%$ of ventral ridges. In female $86 \%$ of rides appear in oesophageal region within same dorsal and ventral ratio. Ridges disappear just anterior to caudal bursa in male and at phamids level in female.

In male, $29,31(28,28,26)$ ridges at oesophagointestinal junction (Fig. 5C) and 32, 35 (30, 33, 34) ridges at mid-body (Fig. 5E). In female, 36 ridges oesophago-intestinal junction (Fig. 5D) and 42 ridges at mid-body (Fig. 5F).

In transversal section, ridges same size, orientated perpendicularly to body surface with regular spacing.

Holotype male: $4200 \mu \mathrm{m}$ long and $100 \mu \mathrm{m}$ wide at mid-body. Cephalic vesicle $50 \mu \mathrm{m}$ long and 30 $\mu \mathrm{m}$ wide. Nerve ring, excretory pore and deirids $130 \mu \mathrm{m}, 210 \mu \mathrm{m}$ and $230 \mu \mathrm{m}$ from apex, respectively. Oesophagus $380 \mu \mathrm{m}$ long (Fig. 5A).

Caudal bursa illustrated in Fig. 6M. Spicules 125 $\mu \mathrm{m}$ long. Blade with spatulate extremity, fork distally divided at $23 \%$ of whole length of spicule (Fig. $5 \mathrm{H}, \mathrm{I}, \mathrm{J})$.

Allotype-female: $9200 \mu \mathrm{m}$ long and $130 \mu \mathrm{m}$ wide at mid-body. Cephalic vesicle $65 \mu \mathrm{m}$ long and 35 $\mu \mathrm{m}$ wide. Nerve ring, excretory pore and deirids $160 \mu \mathrm{m}, 270 \mu \mathrm{m}$ and $290 \mu \mathrm{m}$ from apex, respectively. Oesophagus $480 \mu \mathrm{m}$ long.
Vulva $2850 \mu \mathrm{m}$ from caudal extermity. Vagina vera $30 \mu \mathrm{m}$ long dividing vestibule $220 \mu \mathrm{m}$ long into two equivalent parts. Sphincters both $30 \mu \mathrm{m}$ and infundibula both $20 \mu \mathrm{m}$ long (Fig. 5G). Anterior uterine branch $1900 \mu \mathrm{m}$ long with 38 eggs, posterior uterine branch $1800 \mu \mathrm{m}$ long with 26 eggs. All eggs at morula stage, $70 \mu \mathrm{m}$ long and 50 $\mu \mathrm{m}$ wide. Tail $120 \mu \mathrm{m}$ long and $50 \mu \mathrm{m}$ wide at level of anus with caudal spine $15 \mu \mathrm{m}$ long (Fig. $5 \mathrm{~K})$.

\section{DISCUSSION}

In the neotropical region, the sole species closely related to the specimens described above is Oswaldocruzia taranchoni Ben Slimane and Durette-Desset (1995) a parasite of Bufo marinus from Pernambuco, Brazil which has both the caudal bursa of type III and the spicular blade with spatulate extremity. Unlike the specimens described above, in $O$. taranchoni, the sexual dimorphism concerning the size is slighter (male 6.4-5 $\mathrm{mm}$, female $7.35 \mathrm{~mm}$ ), the ridges are more numerous (53-75 at mid-body in females) and not pronounced, and the division of the spicular fork is deeper. We consider the specimens from Eleutherodactylus as belonging to a new species Oswaldocruzia cassonei $\mathrm{n}$. sp named after our colleague Jimmy Cassone.

\section{Oswaldocruzia petterae $\mathbf{n}$. sp.}

Type material: holotype male, allotype female MHNG-INVE 19500, 1 male, 1 female paratypes MNHN 153 MD

Host:Leptodactylus pentadacylus (Leptodactylidae)

Site: small intestine

Locality: San Pablo, Ecuador

Voucher material: from the same site and the same locality as the types

In 9 L. pentadactylus: 6 males, 5 females, 1 L4 female, MHNG-INVE 19501-505; 3 males, 3 females, MNHN 148 MD, 149 MD, 154 MD, 155 MD.

\section{ADULTS}

Small nematodes, with anterior part of body coiled. Cervical alae absent.

Synlophe: (studied in the male and the female paratypes; in 2 males and 2 females from voucher material. Numbers in brackets correspond to voucher specimens).

In both sexes, cuticle bears longitudinal ridges over whole length of body. In male $82-100 \%$ of ridges appear in oesophageal region within $87-100 \%$ of dorsal ridges and $77-100 \%$ of ventral ridges. In female $90 \%$ of ridges appear in oesophageal region within same dorsal and ventral ratio. Ridges 

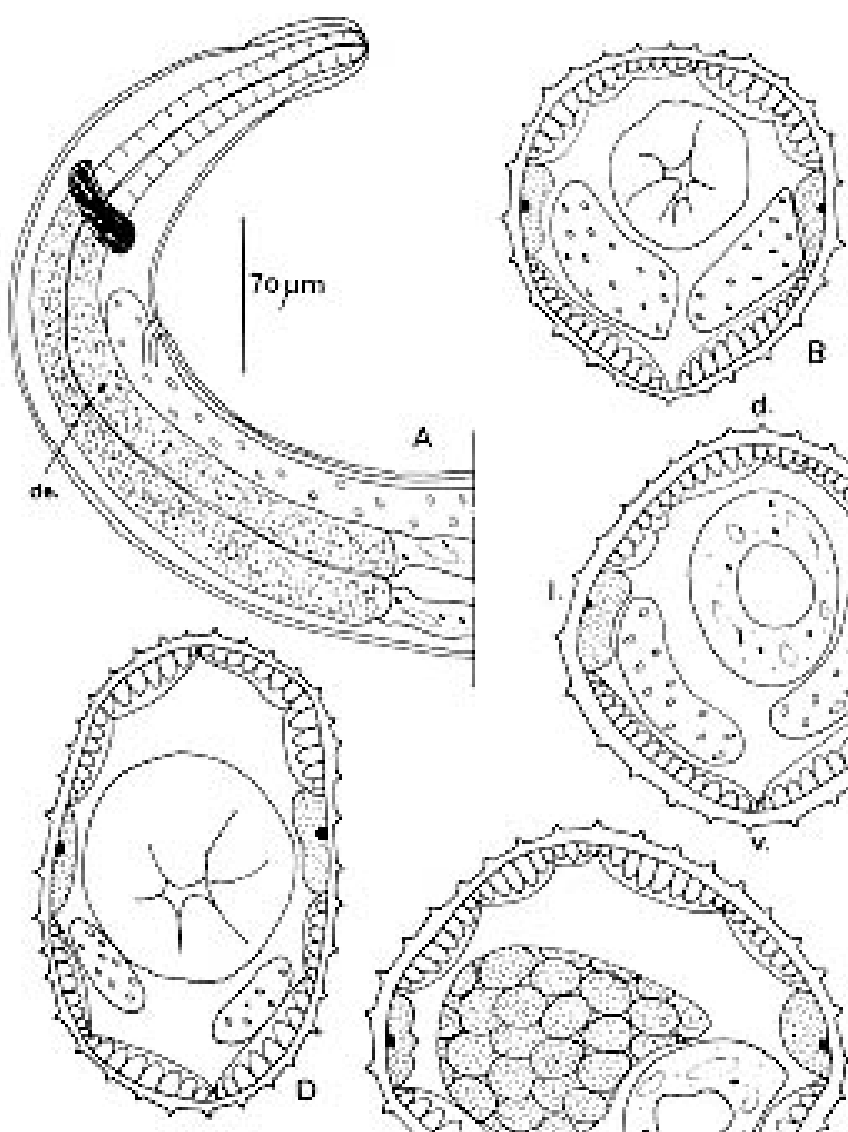

A
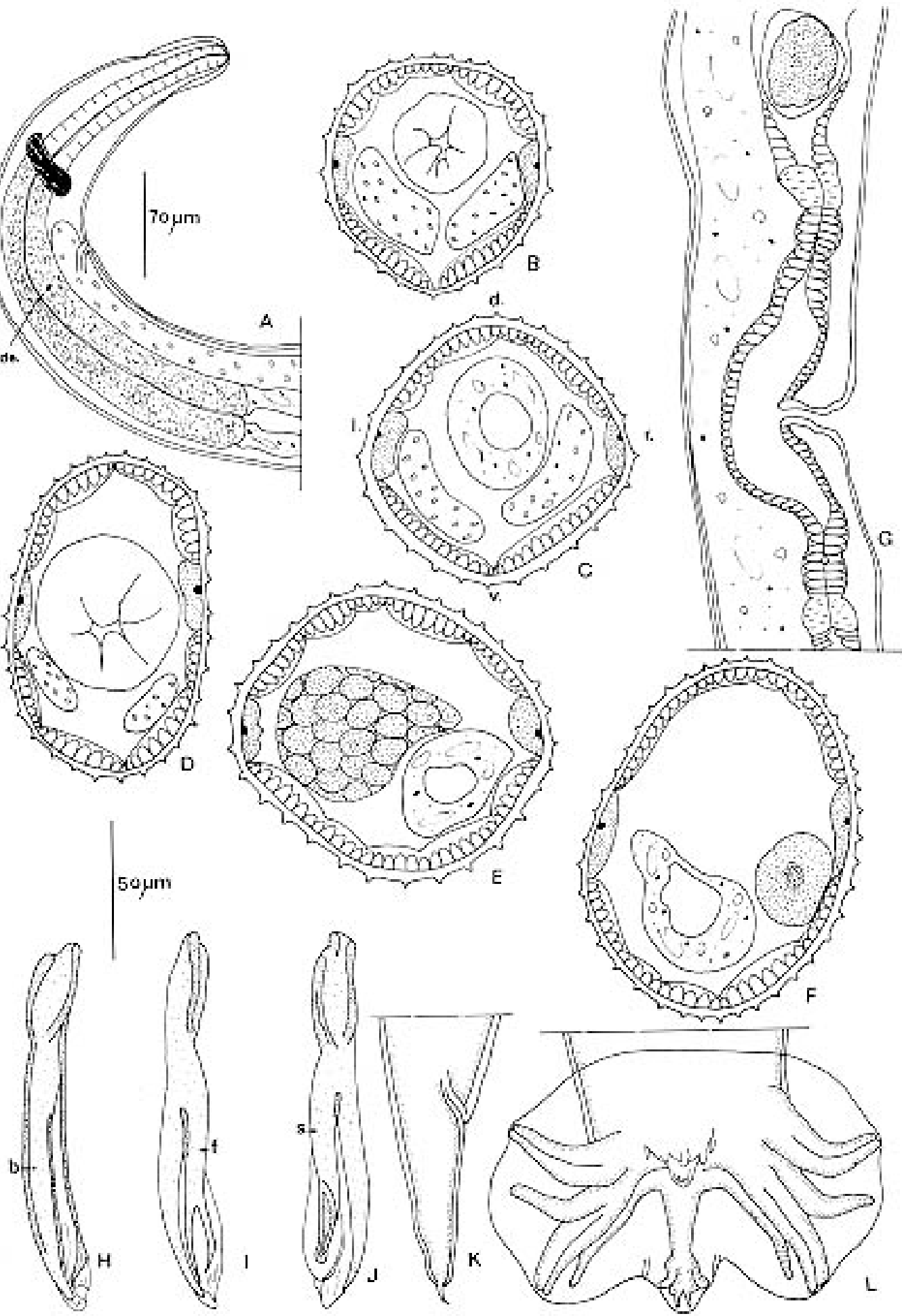

Fig. 5: Oswaldocruzia cassonei n.sp. from Eleutherodactilus lanthanites. A: male, anterior extremity, right lateral view. B to F: synlophe in transversal sections. B: male, at excretory pore level. C: $i d$, at oesophago-intestina1 junction. D: female, id. E: male, at mid-body. F: female, id. G: female, ovejector, right lateral view. H to J: male, dissected spicules. H: externo-lateral view. I: ventral view. J: dorsal view. K: female, tail, right lateral view. L: male, caudal bursa, ventral view. All the sections are orientated as C. A,G,K bar $=70 \mu \mathrm{m}$; B to F, H to J, L, M bar $=50 \mu \mathrm{m}$. Abbreviations: d.= dorsal; v.= ventral; 1.= left; r.= right; $\mathrm{f}=$ fork; $\mathrm{s}=$ shoe; $\mathrm{b}=$ blade; de. $=$ deirid. 


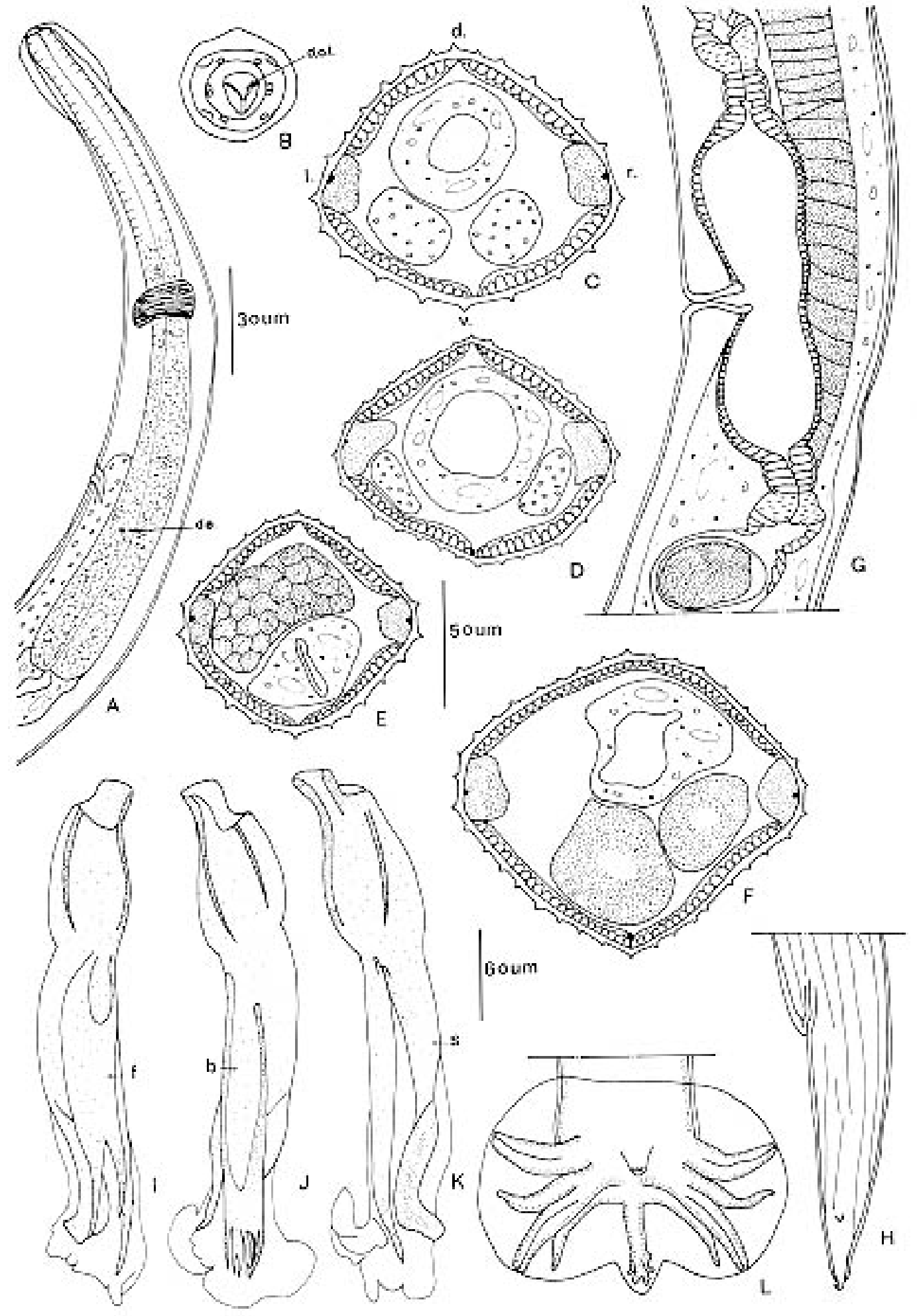

Fig. 6: Oswaldocruzia petterae n. sp. from Leptodactyllus pentadacylus. A: male, anterior extremity, left lateral view. B: male, head, apical view. C to F: synlophe in transversal sections. C: male, oesophago-intestinal junction. D: female, id. E: male, at mid-body. F: female, $i d$. G: female, ovejector, left lateral view. H: female, tail, left lateral view. I to K: male, dissected spicules. I: ventral view. J: externo-lateral view. K: dorsal view. L: male, caudal bursa, ventral view. All the sections are orientated as C. A,G,H,L bar $=60 \mu \mathrm{m}$; B,C, I to K bar $=30 \mu \mathrm{m}$; D to F bar $=50 \mu \mathrm{m}$. Abbreviations: $\mathrm{d} .=$ dorsal; $\mathrm{v} .=\mathrm{ventral} ; 1 .=$ left; $\mathrm{r}=\mathrm{right}$; de.= deirid; d.o.t=dorsal oesophageal tooth. 
disappear just anterior to caudal bursa in male and at phasmids level in female.

In male, $23(26,27)$ ridges at oesophago-intestinal junction (Fig. 6C) and $28(26,30)$ at mid-body (Fig. $6 \mathrm{E})$. In female, $34(33,31)$ ridges at oesophagointestinal junction (Fig. 6D), and $38(41,38)$ at midbody (Fig. 6F).

In transversal section, ridges are orientated perpendicularly to body surface, same size and regularly spaced except in oesophageal region where the ridges in front of lateral fields are more spaced.

Holotype-male: $5000 \mu \mathrm{m}$ long and $90 \mu \mathrm{m}$ wide at mid-body; cephalic vesicle $65 \mu \mathrm{m}$ long and $40 \mu \mathrm{m}$ wide. Nerve ring, excretory pore and deirids 190 $\mu \mathrm{m}, 330 \mu \mathrm{m}$ and $350 \mu \mathrm{m}$ from apex, respectively. Oesophagus $470 \mu \mathrm{m}$ long (Fig. 6A).

Caudal bursa illustrated in Fig. 6 L. Spicules 140 $\mu \mathrm{m}$ long; blade distally divided into 6 processes, fork distally divided at $21 \%$ of whole length of spicule (Fig. 6 I, J, K).

Allotype-female: $9000 \mu \mathrm{m}$ long and $120 \mu \mathrm{m}$ wide at mid-body; cephalic vesicle $80 \mu \mathrm{m}$ long and 35 $\mu \mathrm{m}$ wide. Nerve ring, excretory pore and deirids $200 \mu \mathrm{m}, 350 \mu \mathrm{m}$ and $370 \mu \mathrm{m}$ from apex, respectively. Oesophagus $510 \mu \mathrm{m}$ long

Vulva $3100 \mu \mathrm{m}$ from caudal extremity. Vagina vera $35 \mu \mathrm{m}$ long dividing vestibule $240 \mu \mathrm{m}$ long into two equivalent parts. Sphincters both $25 \mu \mathrm{m}$ long and infundibula both $25 \mu \mathrm{m}$ long (Fig. 6G). Anterior uterine branch $2200 \mu \mathrm{m}$ long with 55 eggs, posterior uterine branch $2200 \mu \mathrm{m}$ long with 52 eggs. All eggs at morula stage $70 \mu \mathrm{m}$ long and $50 \mu \mathrm{m}$ wide. Tail $180 \mu \mathrm{m}$ long and $65 \mu \mathrm{m}$ wide at level of anus, with caudal spine $15 \mu \mathrm{m}$ long (Fig. 6H).

\section{DISCUSSION}

The specimens from Leptodactylus are mainly characterized by (1) a cephalic vesicle without proximal swelling; (2) a synlophe with numerous ridges regularly spaced; (3) the absence of the cervical alae; (4) a caudal bursa of type III and (5) the spicular blades divided into numerous processes at their distal extremities. The only species sharing the same characters is Oswaldocruzia chambrieri Ben Slimane and Durette-Desset (1993), a parasite of Bufo and Eleutherodactylus from the same region as the specimens studied above.
The extra-branches present on the spicular shoes of $O$. chambrieri are not observed in any of the Leptodactylus specimens. Therefore, this character is not constant within the same species and cannot be used as a specific character. Only two differences indicate a speciation: the number of ridges at mid-body level and the length of the spicules both in relation to the size of the specimen. In a female of $O$. chambrieri, $9 \mathrm{~mm}$ long, the number of ridges is 38 and the length of the spicules is $140 \mu \mathrm{m}$. In a $6.4 \mathrm{~mm}$ long female parasite of Leptodactylus, the number of ridges is 54 and the length of the spicules is $190 \mu \mathrm{m}$.

We therefore consider the specimens from Leptodactylus, belonging to a new species Oswaldocruzia petterae n. sp. named after our colleague Dr Annie Petter.

\section{REFERENCES}

Ben Slimane B, Durette-Desset MC 1993. Quatre nouvelles espèces du genre Oswaldocruzia Travassos, 1917 (Nematoda: Trichostrongyloidea) parasites d'Amphibiens d'Equateur. Rev Suisse Zool 100: 113-136.

Ben Slimane B, Durette-Desset MC 1995. Identification d'Oswaldocruzia subauricularis (Rudolphi, 1819) et $O$. mazzai Travassos, 1935 et description de deux nouveaux Oswaldocruzia (Nematoda, Trichostrongylina, Molincoidea) parasites de Bufonidae néotropicaux. Rev Suisse Zool 102: 635653.

Ben Slimane B, Durette-Desset MC, Chabaud AG 1993. Oswaldocruzia (Trichostrongyloidea) parasites d'Amphibiens des Collections du Muséum de Paris. Ann Parasit Hum Comp 68: 88-100.

Ben Slimane B, Verhaagh M, Durette-Desset MC 1995. Oswaldocruzia peruensis n. sp. (Nematoda: Trichostrongylina) parasite d'un Iguanidae de Pérou. Bull Mus Natl Hist Nat Paris 4ème sér 17: 77-82.

Durette-Desset MC 1985. Trichostrongyloid Nematodes and their Vertebrate hosts: Reconstruction of the phylogeny of a parasitic group. Adv Parasitol 24: 239-306.

Durette-Desset MC, Chabaud AG 1981. Nouvel essai de classification des Nématodes Trichostrongyloidea. Ann Paras hum comp 56: 297-312.

Durette-Desset MC, Nasher AK, Ben Slimane B 1992. Oswaldocruzia arabica n.sp.(Nematoda, Trichostrongyloidea) parasite d'un Bufonidae de la péninsule arabique et remarques sur des espèces proches. Bull Mus Natl Hist Nat Paris 4e ser 14: 693-703. 
